\title{
Simultaneous Spontaneous Bilateral Quadriceps Tendon Rupture Related with Hyperparathyrodism Secondary to Vitamin D Deficiency: A Case Report
}

\author{
Hiperparatiroidizme Sekonder Vitamin D Yetmezliğine Bağı íki \\ Taraflı ve Aynı Zamanlı Kuadriseps Tendon Yırtığı Vaka Sunumu
}

Gokcer UZER, Mehmet ELMADAG, Fatih YILDIZ, Mehmet Anil PULATKAN

Department of Orthopaedic and Traumatology, Bezmialem Vakif University, Istanbul, Turkey

ABSTRACT

Spontaneous bilateral quadriceps tendon rupture is a rare injury and is usually observed in cases of diabetes mellitus (DM), rheumatoid arthritis (RA) hyperparathyroidism and chronic renal failure (CRF) or after long-term steroid use. In patients having a risk of misdiagnosis, magnetic resonance imaging (MRI) would help to reach the correct diagnosis. Early diagnosis and appropriate surgical treatment are necessary for successful results. We presented a patient who had bilateral quadriceps tendon rupture related with hyperparathyroidism secondary to Vitamin D deficiency and was treated surgically.

Key Words: Hyperparathiroidism, Vit-D deficiency, quadriceps tendon rupture

\section{ÖZET}

Spontan bilateral kuadriseps tendon yırtığı nadir bir yaralanma olup, sıklıkla diabetes mellitus (DM), romatoid artrit (RA), hiperparatiroidi, kronik böbrek yetmezliği (KBY) hastalığı zemininde veya steroid gibi ilaç kullanımında görülen bir durumdur. İlk başvuruda yanlış tanı konulması riski olan hastalarda iyi bir fizik muayene ve manyetik rezonans görüntüleme (MRG) tetkiki tanıda yardımcı olmaktadır. Erken tanı ve cerrahi tedavi ile başarılı sonuçlara ulaşmak mümkündür. Biz bu yazıda D vitamini eksikliğine ikincil gelişen hiperparatiroidiye bağlı spontan bilateral kuadriseps tendon yırtığı hastasının olgu sunumunu yaptık.

Anahtar Sözcükler: Hiperparatiroidizm, Vit-D yetmezliği, kuadriseps tendon rüptürü

\section{Introduction}

Simultaneous bilateral quadriceps tendon rupture is a rare pathology and is usually seen in patients who have underlying chronic diseases such as hyperparathyroidism, DM, CRF, RA, gout, and systemic lupus erythematous; as well as in patients using anabolic steroids, quinolones, corticosteroids or statins for an extended period of time; or in athletes who perform intensive sportive activities (1-3). Quadriceps tendon rupture in young patients is usually one-sided and depends on an extremely severe work-out $(1,4,5)$.

In these patients, hyperparathyroidism is usually secondary to renal insufficiency and it plays the main role in the pathogenesis of the tendon rupture $(6,7)$. As the treatment of the tendon ruptures are performed early, the more successful results are obtained $(8,9)$. In this study, we discussed an 18 year old female patient with bilateral spontaneous quadriceps tendon rupture.

\section{Case Report}

An 18-year-old female patient referred to a hospital because of pain in both knees, uneasiness of complete extension of the knees and inability to walk. In the story of the patient, none of the diseases such as DM, CRF, RA, gout or steroid use was determined. However, she has been treated for epilepsy (carbamazepine $600 \mathrm{mgr} /$ day) for 10 years and reported no attack in the last 4-5 years. There had been complaints about weakness in the both legs for 1-2 years; nevertheless, no problem had been declared in walking. She stumbled while getting on the bus 4-5 months previously; and the knees had 
ached since then. Medical treatment was applied and the pain decreased; however, weakness in walking started. The pain increased when she stumbled again while walking 3 weeks earlier and inability in raising the legs accompanied the weakness in walking. Then, the patient was referred to our hospital.

Findings of physical examination: Height $158 \mathrm{~cm}$, weight $55 \mathrm{~kg}$ (BMI: 22), atrophy in both of the quadriceps muscles and gaps in bonding places of the tendons to the patella (palpable soft tissue depression proximal to the superior pole of the patella) were observed. Muscle strengths of the bilateral quadriceps was determined as 2/5 and she was unable to carry out straight leg rising. The range of active flexion in the both knees was $100^{\circ}$ and it was painful after that. Antero-posterior and lateral X-rays of both knees showed inferior displacement of the patella; which were not fractured and there was no calcium deposit in the quadriceps tendon (Figure 1). On the MRI, although the left sided quadriceps tendon was completely ruptured from the superior pole of the patella, partial tendon rupture (nearly $30 \%$ of the tendon) was seen on the right side. According to the blood analysis, the levels of blood lipid profile, creatinine $(0,5 \mathrm{mg} / \mathrm{dL} \mathrm{N}$ : 0.5-0.9 mg/ $\mathrm{dL})$, serum Ca $(9 \mathrm{mg} / \mathrm{dL} \mathrm{N}: 8.7-10.4 \mathrm{mg} / \mathrm{dL}), \mathrm{P}(4.3 \mathrm{mmol} / \mathrm{L}$ $\mathrm{N}: 3.5-5.1 \mathrm{mmol} / \mathrm{L})$ and ACTH $(22.74 \mathrm{pg} / \mathrm{mL} \mathrm{N}: 7.2-63.3$ $\mathrm{pg} / \mathrm{mL}$ ) were within the normal ranges. Serum levels of parathyroid hormone (256 pg/Ml N: 19.8-74.9) and ALP (580 $\mathrm{U} / \mathrm{L}$ N: $45-128 \mathrm{U} / \mathrm{L})$ were increased, and the levels of $25-\mathrm{OH}$ Vitamin $\mathrm{D}(<4 \mathrm{ng} / \mathrm{mL}, 0-10 \mathrm{ng} / \mathrm{mL}$ series deficiency), uric $\operatorname{acid}(1.7 \mathrm{mg} / \mathrm{dL} \mathrm{N}: 2.4-5.7 \mathrm{mg} / \mathrm{dL})$ and BUN $(7.94 \mathrm{mg} / \mathrm{dL}$ $\mathrm{N}$ : 9-23 mg/ dL) were decreased.
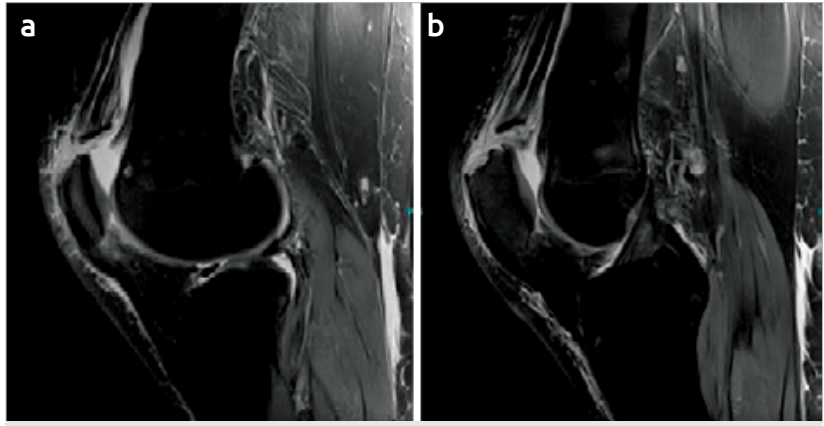

Figure 1. Figure 2. MR imaging of both knees MRI: magnetic resonance imaging

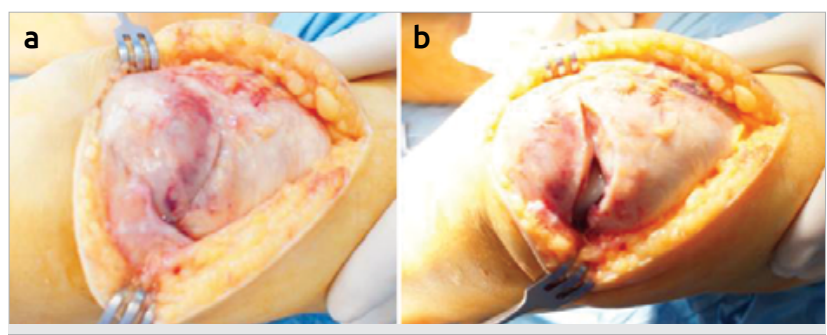

Figure 2. a, b. Peropereative image of the left knee; fibrous tissue occupied the ruptured ends of the tendon in the left knee (a) after the debridement of the ruptured tendon ends (b)
The consent of the patient has been taken by telling the patient that her both quadriceps tendons were ruptured and they had to be surgically repaired so that she could walk more easily.

Both knees of the patient were operated on under general anesthesia, using a tourniquet, in the same session and using $10 \mathrm{~cm}$ of longitudinal anterior approaches. The partially ruptured right quadriceps tendon was repaired end to end, primarily. On the left side, the distal part of the ruptured quadriceps tendon was about $2 \mathrm{~cm}$. After biopsy and debridement of fibrous tissues at the ends of the tendon (Figure 2), the distal end of the proximal part was sutured using nonabsorbable material (No: 5 Ethibond, Johnson\&Johnson, USA) according to the Krackow technique and bone-tendon repair was achieved using Insall's trans patellar tunnel fixation method. The ROM of the knees after repairing was $0-110^{\circ}$ under anesthesia.

On histopathological evaluation, the biopsy material was painted with congo-red and amyloid deposit was not observed.

The knees were kept in $0^{\circ}$ extension for 6 weeks using knee orthosis. In the early postoperative period, passive isometric quadriceps exercises were started between the ranges of $0-50^{\circ}$ flexion. Full weight bearing was allowed using two crutches. After 6 weeks, knee active ROM exercises and quadriceps strengthening exercises were initiated. At the first year of follow-up, passive extension was almost complete in both knees, but there was a $10^{\circ}$ extension lag and active flexion was $80^{\circ}$ (Figure 3).

\section{Discussion}

In our case, unlike the other cases published in the literature, a young female patient had spontaneous and simultaneous quadriceps tendon rupture related with hyperparathyroidism secondary to Vitamin D deficiency. The rupture developed due to a minor trauma; there was no ligament disease, renal insufficiency or long-term use of medications, except carbamazepine for epilepsy. During the early postoperative period, serum PTH and ALP levels were found to be higher and Vitamin D levels lower than the normal levels, thus hyperparathyroidism secondary to Vitamin D deficiency was diagnosed for the first time.

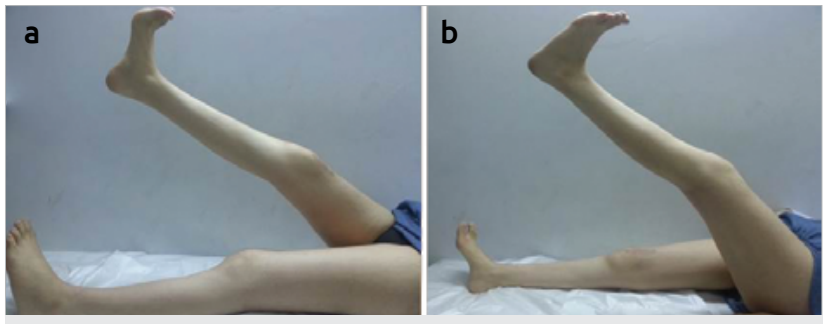

Figure 3. At the last follow-up (first year postoperatively), a $10^{\circ}$ of extension lag and $80^{\circ}$ of flexion were obtained 
The quadriceps tendon is one of the widest tendons of the human body and its rupture is seen rarely. In the study of Neubauer and Larin concerning quadriceps tendon rupture based on the English and German literature, patients were usually male (89\%), above the age of 50 years and the rate of misdiagnosis was up to $30 \%(10,11)$.

Quadriceps tendon rupture generally occurs in the semi-flexion position of the knee during tensioning of the tendon under extra force or its eccentric contraction in order to stabilize while falling. According to the study of Huberti et al. $(2,12)$ the patellar and quadriceps tendons are loaded equally if the knees are kept in $50^{\circ}$ of flexion but the quadriceps tendon is loaded 30\% more than the patellar tendon when the knees were in $90^{\circ}$ of flexion. Painful swelling, loss of extension and a gap in the suprapatellar region (sulcus sign) are findings of the classical triad of the pathology. An MRI usually corrects the diagnosis. Thus, in our case, we suspected the quadriceps tendon rupture according to the physical examination and the diagnosis was corrected by MRI.

Steiner and Palmer published a case with CRF and simultaneous bilateral quadriceps tendon rupture. In the reported cases with bilateral quadriceps tendon rupture secondary to CRF, hyperparathyroidism and long-term hemodialysis have been found to be the main reasons (13-15). Rysavy et al. (16) reported the factors causing quadriceps tendon rupture in case of CRF as degeneration of the tendons due to chronic acidosis, amyloid deposition in the tendons and alteration of their structures, and weakness in the junctional area of the bone and tendon because of osteoclastic activity in hyperparathyroidism.

Muratli et al. (17) evaluated the systemic, local and mechanic factors related to quadriceps tendon rupture, and found that the most important factor is the blood flow to the peripheral ligaments of the tendon and arteries of the muscles. Blood flow to the tendon decreases as a result of the mononuclear cell infiltration after micro trauma and thrombosis of the micro capillary circulation. Therefore, the tendon tends to rupture.

Ryuzaki et al. (18) found that hyperthyroid patients with the tendon ruptures had extremely increased levels of serum alkaline phosphatase. De Franco et al. (19) found the values of serum alkaline phosphatase and parathyroid hormone at the highest level within the 1-month before the tendon rupture. They also claimed that increase in the level of serum parathyroid hormone to $500 \mathrm{pg} / \mathrm{dL}$ is significant.

Hyperparathyroidism developed due to vitamin D deficiency, causes weakness in the junction of the bone and tendon, and may result in spontaneous bilateral quadriceps tendon rupture if left untreated.

\section{Conclusion}

Bilateral simultaneous quadriceps tendon rupture is an unusual pathology and the rate of misdiagnosis is high. It is usually based on an underlying metabolic disease. Good results would be achieved with early diagnosis and an appropriate physical therapy program. As discussed in our study, in bilateral spontaneous quadriceps tendon ruptures in young, non-athletic patients without CRF and long-term medications, secondary hyperparathyroidism should be first considered.

Conflict of Interest: No conflict of interest was declared by the authors.

Peer-review: Externally peer-reviewed.

Informed Consent: Written informed consent was obtained from patients who participated in this study.

Author Contributions: Concept - G.U.; Design - M.E.; Supervision G.U.; Materials - M.A.P.; Data Collection and/or Processing - M.E., M.A.P.; Analysis and/or Interpretation- G.U., M.E.; Literature Review F.Y., M.A.P.; Writing - M.E., F.Y.; Critical Review - G.U., F.Y.; Other G.U., F.Y.

Çıkar Çatışması: Yazarlar çıkar çatışması bildirmemişlerdir.

Hakem değerlendirmesi: Dış bağımsız.

Hasta Onamı: Yazılı hasta onamı bu çalışmaya katılan hastalardan alınmıştır.

Yazar Katkıları: Fikir - G.U.; Tasarım - M.E.; Denetleme - G.U.; Malzemeler - M.A.P.; Veri toplanması ve/veya işlemesi - M.E., M.A.P.; Analiz ve/veya yorum - G.U., M.E.; Literatür taraması - F.Y., M.A.P.; Yazıyı yazan - M.E., F.Y.; Eleştirel İnceleme - G.U., F.Y.; Diğer - G.U., F.Y.

\section{References}

1. Pei, Y.H, P, Huang, L, Chiang, C, Simultaneous bilateral quadriceps tendon rupture in a uremic patient. Formosan Journal of Musculoskeletal Disorders; 2011; 2: 35-9. [CrossRef]

2. Celik EC, Ozbaydar M, Ofluoglu D, Demircay E. Simultaneous and spontaneous bilateral quadriceps tendons rupture. Am J Phys Med Rehabil 2012; 91: 631-4. [CrossRef]

3. Gao MF, Yang HL, Shi WD. Simultaneous bilateral quadriceps tendon rupture in a patient with hyperparathyroidism undergoing long-term haemodialysis: A case report and literature review. J Int Med Res; 2013: 41: 1378-83. [CrossRef]

4. Campbell, J.D., Injuries to the pelvis, hip and thigh, in Sports Medicine, L.Y. Griffin, Editor. American Academy of Orthopaedic Surgeons: Illinois; 1995.p.248-50.

5. Ege, R., Patella kırıkları ve patellayla ilgili yumuşak doku yaralanmaları, in Diz sorunları, R. Ege, Editor. Dizgi Baskı: Ankara; 1998.p.1053-6.

6. Steiner, C.A. and L.H. Palmer. Simultaneous bilateral rupture of the quadriceps tendon. Am J Surg 1949; 78: 752-5. [CrossRef]

7. Shah, M.K. Simultaneous bilateral quadriceps tendon rupture in renal patients. Clin Nephrol 2002; 58: 118-21. [CrossRef]

8. Trobisch PD, Bauman M, Weise K, Stuby F, Hak DJ. Histologic analysis of ruptured quadriceps tendons. Knee Surg Sports Traumatol Arthrosc 2010; 18: 85-8. [CrossRef]

9. O'Shea K, Kenny P, Donovan J, Condon F, McElwain JP. Outcomes following quadriceps tendon ruptures. Injury 2002; 33: 257-60. [CrossRef]

10. Neubauer T, Wagner M, Potschka T, Riedl M. Bilateral, simultaneous rupture of the quadriceps tendon: a diagnostic pitfall? Report 
of three cases and meta-analysis of the literature. Knee Surg Sports Traumatol Arthrosc, 2007; 15: 43-53. [CrossRef]

11. Shah, M.K., Simultaneous bilateral rupture of quadriceps tendons: analysis of risk factors and associations. South Med J 2002; 95: 860-6. [CrossRef]

12. Esenyel CZ, Oztürk K, Cetiner K, Yeşiltepe R, Kara AN. [Quadriceps tendon ruptures: evaluation and treatment]. Acta Orthop Traumatol Turc 2005; 39: 150-5.

13. Basic-Jukic N, Juric I, Racki S, Kes P. Spontaneous tendon ruptures in patients with end-stage renal disease. Kidney Blood Press Res 2009; 32: 32-6. [CrossRef]

14. Bhole, R., J.C. Flynn, and T.C. Marbury. Quadriceps tendon ruptures in uremia. Clin Orthop Relat Res 1985: 200-6.

15. Lombardi, L.J., Cleri D.J, Epstein E, Bilateral spontaneous quadriceps tendon rupture in a patient with renal failure. Orthopedics 1995; 18: 187-91.
16. Rysavy M, Wozniak A, and Arun K.P, Spontaneous and simultaneous quadriceps and patella tendon rupture in a patient on chronic hemodialysis. Orthopedics 2005; 28: 603-5.

17. Muratli HH, Celebi L, Hapa O, Biçimoğlu A. Simultaneous rupture of the quadriceps tendon and contralateral patellar tendon in a patient with chronic renal failure. J Orthop Sci, 2005; 10: 227-32. [CrossRef]

18. Ryuzaki M, Konishi K, Kasuga A, Kumagai H, Suzuki H, Abe S, et al. Spontaneous rupture of the quadriceps tendon in patients on maintenance hemodialysis--report of three cases with clinicopathological observations. Clin Nephrol 1989; 32: 144-8.

19. De Franco P, Varghese J, Brown WW, Bastani B. Secondary hyperparathyroidism, and not beta 2-microglobulin amyloid, as a cause of spontaneous tendon rupture in patients on chronic hemodialysis. Am J Kidney Dis 1994; 24: 951-5. 